\title{
Synchronous co-expression of Id-1 and nuclear NF-кB p65 promotes cervical cancer progression and malignancy, and is associated with a poor prognosis and chemosensitivity
}

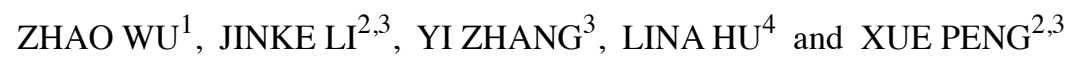 \\ ${ }^{1}$ Department of Obstetrics and Gynecology, Sichuan Academy of Medical Sciences and \\ Sichuan Provincial People's Hospital, Chengdu, Sichuan 610072; \\ ${ }^{2}$ Department of Obstetrics and Gynecology, West China Second University Hospital, Sichuan University; \\ ${ }^{3}$ Key Laboratory of Birth Defects and Related Diseases of Women and Children (Sichuan University), \\ Ministry of Education, Chengdu, Sichuan $610041 ;{ }^{4}$ Department of Obstetrics and Gynecology, \\ Second Affiliated Hospital, Chongqing Medical University, Chongqing 410010, P.R. China
}

Received April 11, 2019; Accepted August 2, 2019

DOI: $10.3892 / o r .2019 .7301$

\begin{abstract}
Although inhibitor of differentiation 1 (Id-1) and $\mathrm{NF}-\kappa \mathrm{B}$ have been shown have play a role in tumorigenesis, their mechanisms and exact roles in cervical cancer have not yet been addressed. This study aimed to investigate the clinical significance of Id-1 and NF- $\mathrm{KB}$ p65 in cervical cancer and to elucidate their roles in malignant properties. Paraffin-embedded cervical tissue specimens $(n=85)$ were collected for immunohistochemistry and survival analysis. Targeting Id-1 with lentivirus in vitro allowed the examination of the NF- $\mathrm{KB}$ signaling pathway and cell survival. The results demonstrated the elevated co-expression of Id-1 and nuclear $\mathrm{NF}-\mathrm{KB}$ p65 was more frequently associated with aggressive cervical cancer behavior and poorer clinical outcomes. Targeting Id-1 with short hairpin RNA or Id-1 overexpression lentivirus in SiHa cells demonstrated that Id-1 is associated with nuclear NF-кB p65 expression and cell survival capacity. The physical interaction between Id-1 and NF- $\kappa$ B p65 was validated in $\mathrm{SiHa}$ cells. Moreover, the survival-promoting or chemoresistant effects of Id-1 may be attributed to the subsequent activation of NF- $\kappa \mathrm{B}$ signaling. On the whole, the synchronous co-expression of Id-1 and nuclear NF- $\kappa$ B p 65 has a prominent role in cervical cancer, suggesting a combined analysis of Id-1 and NF- $\kappa \mathrm{B}$ may help to predict malignant properties and prognosis. Aside from NF- $\mathrm{kB}$, Id-1 may also
\end{abstract}

Correspondence to: Dr Xue Peng, Department of Obstetrics and Gynecology, West China Second University Hospital, Sichuan University, 3rd Section, 20 South Renmin Road, Chengdu, Sichuan 610041, P.R. China

E-mail: pengxuesnow@aliyun.com

Key words: inhibitor of differentiation $1, \mathrm{NF}-\kappa \mathrm{B}$, cervical cancer, progression, prognosis be developed as a promising therapeutic strategy for cervical cancer.

\section{Introduction}

Cervical cancer ranks as the fourth most common type of cancer and the fourth leading cause of cancer-related mortality in women worldwide (1). Although the persistent infection of high-risk human papillomaviruses (HPV) has been demonstrated to be associated with the development of cervical cancer by epidemiological, molecular and functional studies (2), the molecular mechanisms underlying the transition from HPV infection to cervical carcinogenesis and progression are not yet fully understood.

Inhibitor of differentiation 1 (Id-1) is a member of the helix-loop-helix (HLH) transcription factor family (3). As the protein lacks the basic domain for DNA binding, Id-1 acts as the dominant inhibitor of the basic HLH transcription proteins by forming heterodimers. It has been indicated that Id-1 is involved in cell differentiation, proliferation, invasion, apoptosis and chemoresistance (4). Recently, Id-1 has been suggested as a possible oncogene. Overexpression of Id-1 has been found in numerous types of cancer, including gastric carcinoma (5), hepatocellular carcinoma (6), breast cancer (7) and prostate cancer (8). Our previous study also found that increased Id-1 expression was associated with aggressive behavior of cervical cancer and poor overall survival (9). Although Id-1 has been extensively investigated in recent years, the molecular mechanisms of Id-1 in cervical cancer development have not yet been addressed.

$\mathrm{NF}-\kappa \mathrm{B}$ is a prominent survival-regulatory transcription factor that can be activated by various stimuli (10). The predominant form of active $\mathrm{NF}-\kappa \mathrm{B}$ in cells consists of a p65/p50 heterodimer, which is sequestered as an inactive state in the cytoplasm by the inhibitor of $\kappa \mathrm{B}(\mathrm{I} \kappa \mathrm{B})$ protein. The phosphorylation and degeneration of $\mathrm{I} \kappa \mathrm{B}$ releases $\mathrm{NF}-\kappa \mathrm{B}$ and promotes its translocation into the nucleus, where it binds to target genes $(11,12)$. It has been previously demonstrated that 
$\mathrm{NF}-\kappa \mathrm{B}$ p65 is significantly activated in cervical cancer and is associated with cancer progression (13). However, the mechanisms responsible for NF- $\kappa \mathrm{B}$ activation in cervical cancer have not yet been well determined.

Although Id-1 and NF- $\mathrm{NB}$ are known to be associated with tumor development and progression, limited studies are available regarding the association between Id-1 and NF- $\mathrm{BB}$ in the uterine cervix. In this study, clinical and laboratorial evidence was used to assess the co-expression status of Id-1 and $\mathrm{NF}-\kappa \mathrm{B}$, and their prognostic significance in cervical cancer. Furthermore, the effects of silencing or promoting Id-1 gene expression on the $\mathrm{NF}-\kappa \mathrm{B}$ signaling pathway, properties and chemoresistance in vitro were investigated.

\section{Materials and methods}

Human tissues. Paraffin-embedded cervical tissue samples (normal, $\mathrm{n}=20$; squamous cervical cancer, $\mathrm{n}=65$ ) were collected from the Pathology Department of West China Second Hospital, Sichuan University during the year 2006. The details of these samples had been previously described (14). The human investigations were approved by and carried out in accordance with an assurance filed with the Ethics Committee of the West China Second University Hospital, Sichuan University. Moreover, informed consents were obtained from all the patients.

Immunohistochemistry (IHC). The procedure of IHC has been previously described (14). This analysis was performed to detect the specificity of mouse anti-human Id-1 (sc-133104) and NF-кB p65 (sc-135769) antibodies (diluted 1:100; Santa Cruz Biotechnology, Inc.) in cervical tissue samples. Horse anti-mouse IgG (PK-4002, 1:200 dilution in PBS; Zhongshan Jinqiao Biotechnology Co., Ltd., Beijing, China) was used as secondary antibody. Cells with brown staining in the cytoplasm or nucleus were considered positive. Five fields of view (magnification, $\mathrm{x} 40$ ) were selected for each slice and the percentage of positive cells was calculated. The immunoreactivities were assessed as a continuum from the undetected level $(0 \%)$ to diffused staining $(100 \%)$, and the positive immunoreactivity was defined as $>10 \%$.

Cells and cell culture. The human cervical cancer cell lines, HeLa and SiHa, and the E6/E7 immortalized human cervical epithelial cell line (H8), were all obtained from the China Center for Type Culture Collection [obtained in October, 2016; cell line characterizations were performed by DNA (STR) profiling]. Four stable reconstructive cell lines were established as follows: SiHa-knock down (KD) cells (infected with pGIPZ-hId-1-shRNAmir lentivirus,Sequences (target sequence was underlined): Sense 5'-AAAAGGAGCTGAACTCTGAGT CTGACTCGAGTCAGACTCAGAGTTCAGCTCC-3', antisense 5'-GGAGCTGAACTATGAGTCTGACTCGAGTCA GACTCAGAGTTCAGCTCCTTTT-3'), SiHa-KD-control cells (infected with pGIPZ-shRNAmir-control lentivirus, Sequences (target sequence was underlined): Sense 5'-AAA ATTCTCACGAACGTAGTCACGTCTCGAGACGTGACT ACGTTCGTGAGAA-3', antisense 5'-TTTTTTCTCACGAAC GTAGTCACGTCTCGAGACGTGACTACGTTCGTGAGA A-3'), SiHa-Id-1 cells (infected with pWPI-hId-1 lentivirus) and SiHa-Id-1-control cells (infected by empty-pWPI-vector lentivirus), respectively. The Id-1 vectors and viral packaging system were kindly provided by Professor Wenming $\mathrm{Xu}$, Sichuan University. The SiHa cells were inoculated in 6-well plates at $5 \times 10^{5}$ cells/well. When the cells grew to $80 \%$ confluence, the medium was replaced with medium/Polybrene (5 $\mu \mathrm{g} / \mathrm{ml}$; Santa Cruz Biotechnology, Inc.) mixture, and lentiviral particles ( $\left.1 \times 10^{5} \mathrm{IFU}\right)$ were added to the culture. All cells were maintained in RPMI-1640 or DMEM medium (Gibco; Thermo Fisher Scientific, Inc.) supplemented with 10-15\% fetal bovine serum (Gibco; Thermo Fisher Scientific, Inc.) and antibiotics $(100 \mu \mathrm{g} / \mathrm{ml}$ streptomycin and $100 \mathrm{U} / \mathrm{ml}$ penicillin; Gibco; Thermo Fisher Scientific, Inc.) at $37^{\circ} \mathrm{C}$ in $5 \% \mathrm{CO}_{2}$.

Transient transfections. The $\mathrm{H} 8$ cells were transfected with pcDNA expression plasmid Id-1 which contains the full-length human Id-1 gene or pcDNA3.1(-) as the control (kindly provided by Professor Xia Wang, Sichuan University). Transient transfections were performed using the FuGENE 6 transfection reagent (Promega Corporation) according to the manufacturers' recommendations. The siRNA oligonucleotides for Id-1 (sequences: Sense, 5'-CGACAUGAACGGCUG UUACTT-3', antisense, 5'-GUA ACAGCCGUUCAUGUC GTT-3') and non-targeting siRNA as the control (sequences: Sense, 5'-UUCUCCGAACGUGUCACGUTT-3', antisense, 5'-ACGUGACACGUUCGGAGAATT-3') (Santa Cruz Biotechnology, Inc.) were transiently transfected into $\mathrm{SiHa}$ cells using Lipofectamine ${ }^{\circledR} 2000$ (Invitrogen; Thermo Fisher Scientific, Inc.) according to the manufacturer's protocol. After incubation for $4 \mathrm{~h}$, the medium was removed and replaced with fresh medium. Cells were collected at the indicated time points $(0,15,30,60$ and $120 \mathrm{~min})$. The expression of nuclear NF-кB p65 and Id-1 was examined by western blot analysis.

$N F-\kappa B$ reporter gene assay. In order to detect $N F-\kappa B$ transcriptional activity, a dual-luciferase reporter gene assay (Promega Corporation) was used according to the manufacturer's instructions. The cells were co-transfected with the pGL4.32 (luc2P/NF-кB-RE/Hygro) plasmid and pRL-TK-Luc reference plasmid (Lipofectamine ${ }^{\circledR} 2000$ ). After 48 h, cell lysates were analyzed for luciferase assay by Thermo Scientific Varioskan ${ }^{\circledR}$ Flash (Thermo Fisher Scientific, Inc.). NF- $\kappa$ B transcriptional activity was calculated as relative luciferase units ratio of $\mathrm{pNF}-\kappa \mathrm{B}-\mathrm{Luc} / \mathrm{pRL}-\mathrm{TK}-\mathrm{Luc}$.

Reverse transcription-quantitative PCR (RT-qPCR). Total RNA was isolated from the cultured cells and reverse transcribed into cDNA using TRIzol reagent (Invitrogen; Thermo Fisher Scientific, Inc.) and the PrimeScript RT reagent kit (Takara Biotechnology Co., Ltd.) with following protocol: $15 \mathrm{~min}$ at $37^{\circ} \mathrm{C}$ and $5 \mathrm{sec}$ at $85^{\circ} \mathrm{C} . \beta-2$-microglobulin (B2M) was detected as an internal reference. The sequences of the primers were as follows: Human Id-1, forward 5'-TCG GGCTTCCACCTCATTT-3' and reverse 5'-CTCCACCTT GCTCACCTTGC-3'; human B2M, forward 5'-ATGAGT ATGCCTGCCGTGTGA-3' and reverse 5'-GGCATCTTC AAACCTCCATG-3'. PCR was performed using the CFX96 real-time system using SsoFast EvaGreen ${ }^{\circledR}$ Supermix kit (Bio-Rad Laboratories, Inc.) with the following protocol: $20 \mathrm{sec}$ at $95^{\circ} \mathrm{C}, 2 \mathrm{sec}$ at $98^{\circ} \mathrm{C}$ and $5 \mathrm{sec}$ at $65^{\circ} \mathrm{C}$ (40 cycles). 
The relative gene expression (folds) was calculated using the $2^{-\Delta \Delta \mathrm{Cq}}$ method (15).

Western blot analysis. Whole-cell proteins and nuclear extracts from the cultured cells were prepared using the BCA Protein Extraction kit (Beyotime Institue of Biotechnology). Protein concentration was quantified by BCA Protein Assay kit (Beyotime Institue of Biotechnology). Cell proteins $(100 \mu \mathrm{g})$ were loaded onto a 10-15\% gel for SDS-PAGE, and then transferred onto a PVDF membrane (EMD Millipore). The membranes were blocked with 5\% skim milk for $1 \mathrm{~h}$ at room temperature and then incubated with primary antibodies against

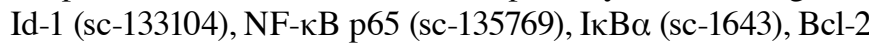
(sc-7382), Bcl-xl (sc-8392), Survivin (sc-17779), X-linked inhibitor of apoptosis (XIAP, sc-55550), inhibitor of apoptosis-1 (IAP-1, sc-271419), inhibitor of apoptosis-2 (IAP-2, sc-517317), Bax (sc-7480), Bak (sc-517390), histone H1 (sc-393358) and $\beta$-actin (sc-47778) (Santa Cruz Biotechnology, Inc.) overnight at $4^{\circ} \mathrm{C}$. After washing, the membrane was incubated with HRP labelled goat anti-mouse IgG (ZB-2305; Zhongshan Jinqiao Biotechnology Co., Ltd., Beijing, China) for $1 \mathrm{~h}$ at room temperature. Finally, protein signals were visualized using the eECL Western Blot Kit (CoWin Biosciences, Inc.) using the ChemiDoc XRS system (Bio-Rad Laboratories, Inc.).

Co-immunoprecipitation analysis. Whole-cell proteins from the SiHa cells were extracted using cell lysis buffer. This extraction was then divided into four equal volume samples (1-4), and the volumes of samples 1-3 were made up to $500 \mu \mathrm{l}$ with ice-cold PBS. Antibody-IgG was added to sample 2 (diluted 1:500), and antibody Id-1/NF- $\kappa$ B p65 was added to sample 3 (diluted 1:500), while sample 1 was supplemented only with ice-cold PBS as the blank control. Samples 1-3 were rocked at $4^{\circ} \mathrm{C}$ for $5 \mathrm{~h}$, and subsequently $10 \mu \mathrm{l}$ Protein A/G PLUS-Agarose beads (Santa Cruz Biotechnology, Inc.) was added and rocked overnight at $4^{\circ} \mathrm{C}$. Subsequently, the beads were pelleted at $\sim 1,000 \mathrm{x} \mathrm{g}$ for $5 \mathrm{~min}$ and washed three times in ice-cold PBS. Samples 1-3 were resuspended in $10 \mu \mathrm{l}$ ice-cold PBS and mixed with $10 \mu 12 X$ SDS loading buffer, together with sample 4 , then subjected to SDS-PAGE on a $12 \%$ gel. The subsequent procedure was essentially the same as that of the western blot analysis described above.

Proliferative and cytotoxicity assay. For the cell proliferation assay, $5 \times 10^{3}$ cells/well were plated into a 96-well plate and incubated for 7 days at $37^{\circ} \mathrm{C}$ in $5 \% \mathrm{CO}_{2}$. For this assay, every $24 \mathrm{~h} 10 \mu \mathrm{l} /$ well WST-1 (Roche Diagnostics) was added to the cells and incubated for $4 \mathrm{~h}$ at $37^{\circ} \mathrm{C}$. Subsequently, the absorbance of the samples against a background control was measured at $440 \mathrm{~nm}$ by an enzymatic labeling instrument (Thermo Fisher Scientific, Inc.), which was regarded as the indicator of viable cells. For cell cytotoxicity assay, $5 \times 10^{4}$ cells/well were plated into a 96 -well plate and incubated at $37^{\circ} \mathrm{C}$ for $24 \mathrm{~h}$. Various different concentrations of cisplatin $(0,5$ and $10 \mu \mathrm{g} / \mathrm{ml})$ were then added to the medium for $24 \mathrm{~h}$ of co-incubation. A WST assay was then performed out to detect cell viability as described above.

Cell migration assay. The wound healing assay was used to examine directional cell migration in vitro. The cells were seeded into a 6-well plate and incubated for $24 \mathrm{~h}$ until a confluent monolayer was formed. Cells were subsequently serum-starved, and linear wounds of similar width were created by manually scraping the cell monolayer with sterile plastic tips. Images were acquired at 0 and $48 \mathrm{~h}$ under a microscope (Nikon Corporation), and the width of the wounds were evaluated by using the reference mark (the cell boundary marked with a white line). The percentage of cell migration was calculated using the following formula: (Width of the wound at $0 \mathrm{~h}$-width of the wound at $48 \mathrm{~h}$ )/width of the wound at $0 \mathrm{~h}$.

Matrigel invasion assay. The cell invasion assay was performed using Transwell Chambers (Corning, Inc.) with an $8-\mu \mathrm{m}$ pore membrane inserted into a 24-well plate. The upper membranes of the Transwell chambers were coated with $40 \mu$ l Matrigel (BD Biosciences) for $4 \mathrm{~h}$ at $37^{\circ} \mathrm{C} .1 \times 10^{4}$ cells in serum-free medium were added into the upper chamber, while the lower chamber was supplemented with $600 \mu 1$ serum-containing medium (15\%). After 48 h, non-invaded cells were scraped off with a cotton swab from the upper side of the chambers. Cells on the lower side of the chambers were fixed and stained with $0.1 \%$ crystal violet for $20 \mathrm{~min}$ at room temperature. The number of invaded cells was counted under a microscope (Nikon Corporation).

Detection of apoptotic cells by 5,5',6,6'-tetrachloro1,1',3,3'tetraethylbenzimidazolylcarbocyanine iodide (JC-1) staining. JC-1 (Beyotime Institute of Biotechnology) is a fluorescent cationic dye widely used for measuring mitochondrial membrane potential ( $\Psi \Delta \mathrm{m})$, which is a hallmark of apoptosis. $5 \times 10^{4}$ cells/well were cultured in a 24 -well plate. Various concentrations of cisplatin were then added to the medium for $24 \mathrm{~h}$. After washing the cells, $500 \mu \mathrm{l} 1 \mathrm{X} \mathrm{JC}-1$ reagent solution was added followed by incubation at $37^{\circ} \mathrm{C}$ for $20 \mathrm{~min}$. Finally, the cells were observed under a fluorescence microscope (Nikon Eclipse Ti; Nikon Corporation). The percentage of survival cells was calculated using the following formula: The number of viable cells/the total number of cells.

Statistical analysis. The patient characteristics were compared using Fisher's exact test. One-way ANOVA or multivariate analysis of variance (post hoc test: Least significant difference) were used where appropriate. The Kaplan-Meier method and the log-rank test were performed to assess the univariate cumulative survival. Pearson's correlation test was used for correlation analysis. Multivariate analysis was performed using a Cox regression model analysis. For all tests, $\mathrm{P}<0.05$ (two-sided) was considered to indicate a statistically significant difference.

\section{Results}

Co-expression of Id-1 and nuclear $N F-\kappa B$ p65 in cervical cancer tissues. Id-1 immunopositivity was most abundant in the cytoplasm of the tumor cells, whereas NF- $\kappa$ B p65 was predominantly detected within the nucleus of the tumor cells (Fig. 1A). Essentially, no immunoreactivity for Id-1 or nuclear NF- $\mathrm{B}$ p65 was observed in the 20 normal samples 
A
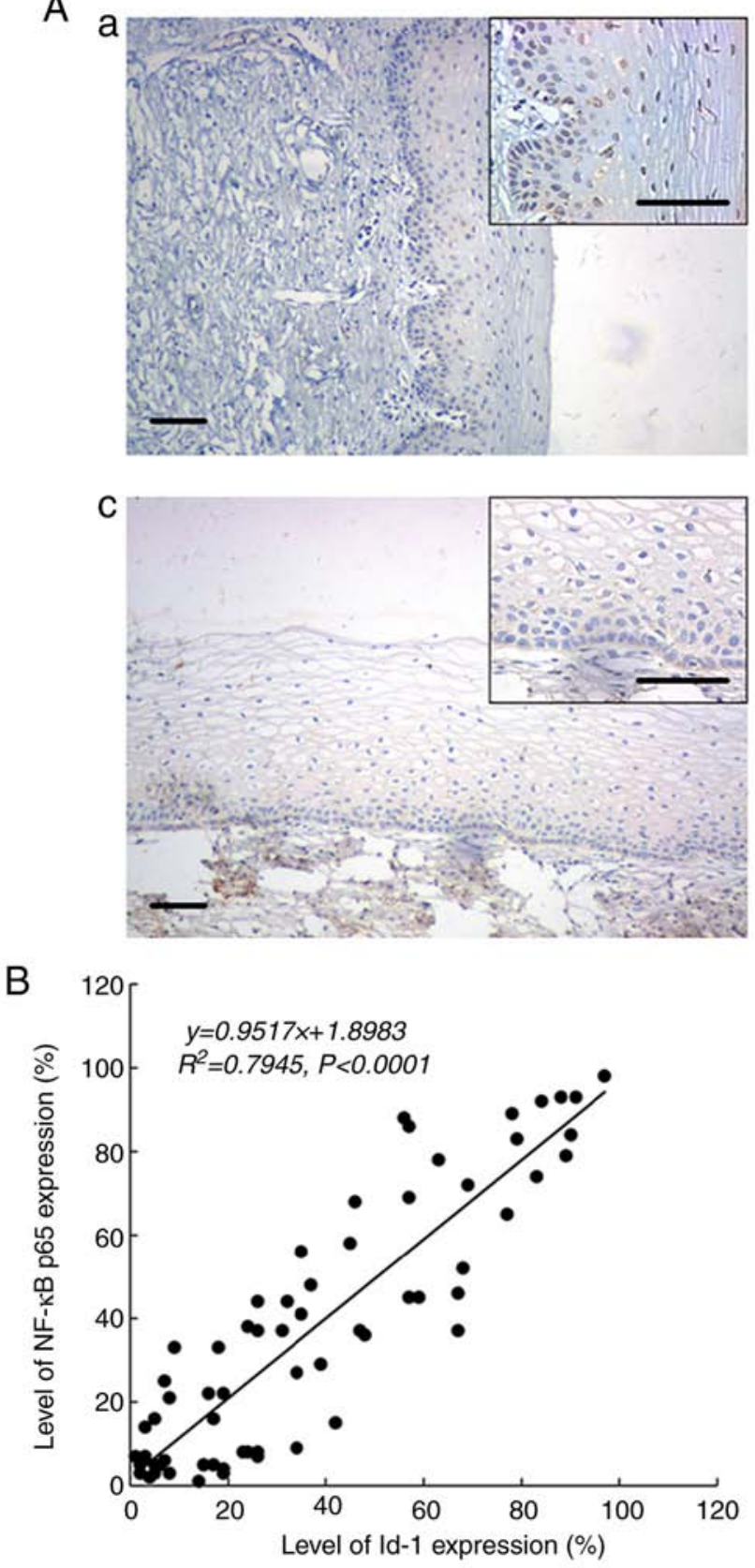

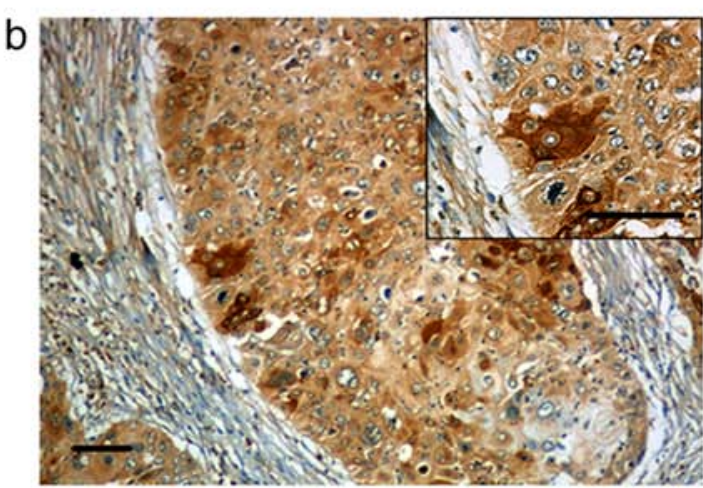

d

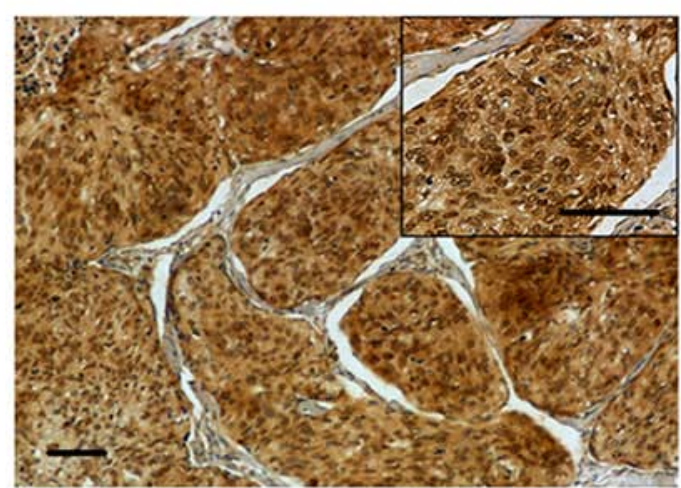

$\mathrm{C}$

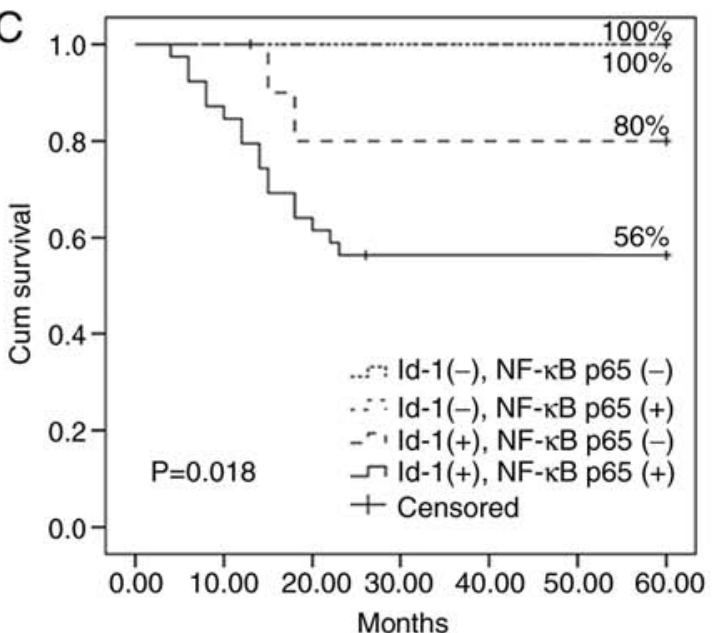

Figure 1. Synchronous co-expression of Id-1 and nuclear NF- $\mathrm{B}$ p65 in clinical tissues, and its correlation to prognosis. (A) Immunohistological detection. Id-1 in (A-a) normal and (A-b) cervical cancer tissues, nuclear NF- $\kappa$ B p65 in (A-c) normal and (A-d) cervical cancer tissues. Representative images (x100, and $\mathrm{x} 400$ for the inserts) are shown. Scale bar, $100 \mu \mathrm{m}$. (B) Pearson's linear regression analysis between expression levels of Id-1 and nuclear NF- $\kappa \mathrm{B}$ p65 is shown. (C) Comparison of the 5-year cumulative survival rate according to the immunopositivity of Id-1 and nuclear NF- $\kappa \mathrm{B}$ p65 is shown. Kaplan-Meier curves and log rank P-value are presented. Id-1, inhibitor of differentiation 1.

( 5 and $11 \%$, respectively). However, in the 65 cancer tissues, diffused Id-1 or focal NF- $\mathrm{B}$ p65 staining was frequently detected ( 75.4 and $67.7 \%$, respectively). Moreover, the expression status of Id-1 and nuclear NF- $\kappa$ B p 65 exhibited a significant positive association (Table I). Of the 65 cancer samples, 39 (60\%) exhibited the co-expression of Id-1 and nuclear NF- $\mathrm{B}$ p65. There was a significant difference in the positive rates of nuclear NF- $\kappa \mathrm{B}$ p65 in the Id-1 negative and Id-1 positive group [Table I, 5/16 and 39/49 (31.3 vs. 79.6\%); $\mathrm{P}=0.001]$. Additionally, there was a strong linear correlation between the NF- $\kappa \mathrm{B}$ p65 and Id-1 expression (Pearson's correlation; $\mathrm{R}^{2}=0.7945 ; \mathrm{P}<0.001$; Fig. 1B).
Association of Id-1 and NF- $\kappa B$ p65 expression with patient characteristics and prognosis. All patients were stratified into the four groups according to the immunopositivity of Id-1 and nuclear NF- $\mathrm{B}$ p65 (Table I): 'a' Id-1 negative/nuclear $\mathrm{NF}-\kappa \mathrm{B}$ p65-negative group; ' $\mathrm{b}$ ' Id-1 negative/nuclear $\mathrm{NF}-\kappa \mathrm{B}$ p65-positive group; 'c' Id-1 positive/nuclear NF-кB p65-negative group; 'd' Id-1-positive/nuclear NF- $\kappa \mathrm{B}$ p65-positive group. In addition to the clinical stages and tumor size, significant differences were found in terms of histological grade, lymph node metastasis, vascular invasion or invasive interstitial depth in the four groups. The 'd' group exhibited a tendency to be more frequently associated with cervical cancer progression 
Table I. Association of Id-1 and nuclear NF- $\mathrm{kB}$ p65 expression with patient characteristics.

\begin{tabular}{|c|c|c|c|c|c|}
\hline \multirow[b]{2}{*}{ Characteristics } & \multicolumn{2}{|c|}{ Id-1 (-) $(\mathrm{n}=16)$} & \multicolumn{2}{|c|}{ Id-1 (+) $(n=49)$} & \multirow[b]{2}{*}{ P-value } \\
\hline & NF-кB p65 (-) (a) & NF- $\kappa$ B p65 (+) (b) & NF-кB p65 (-) (c) & $\mathrm{NF}-\kappa \mathrm{B}$ p65 (+) (d) & \\
\hline No. of patients & 11 & 5 & 10 & 39 & 0.001 \\
\hline FIGO stage & & & & & 0.108 \\
\hline I-II & 8 & 2 & 4 & 29 & \\
\hline III-IV & 3 & 3 & 6 & 10 & \\
\hline Histological grades & & & & & 0.002 \\
\hline WDSCC & 9 & 1 & 2 & 8 & \\
\hline MDSCC + PDSCC & 2 & 4 & 8 & 31 & \\
\hline Lymph node metastasis & & & & & 0.026 \\
\hline No & 10 & 2 & 4 & 17 & \\
\hline Yes & 1 & 3 & 6 & 22 & \\
\hline Vascular invasion & & & & & 0.001 \\
\hline No & 11 & 4 & 5 & 14 & \\
\hline Yes & 0 & 1 & 5 & 25 & \\
\hline Invasive interstitial depth & & & & & 0.009 \\
\hline$\leq 1 / 2$ & 9 & 1 & 4 & 11 & \\
\hline$>1 / 2$ & 2 & 4 & 6 & 28 & \\
\hline Tumor size & & & & & 0.912 \\
\hline Diameter $\leq 4 \mathrm{~cm}$ & 5 & 2 & 6 & 19 & \\
\hline Diameter $>4 \mathrm{~cm}$ & 6 & 3 & 4 & 20 & \\
\hline
\end{tabular}

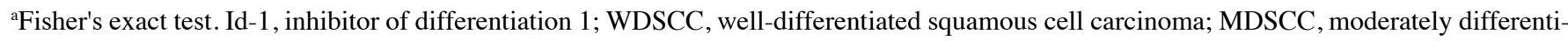
ated squamous cell carcinoma; PDSCC, poorly differentiated squamous cell carcinoma.

Table II. Relationship between Id-1 and nuclear NF- $\mathrm{kB}$ p65 expression and survival.

\begin{tabular}{|c|c|c|c|c|}
\hline \multirow[b]{2}{*}{ Prognostic variants } & \multicolumn{2}{|c|}{ Univariate analysis } & \multicolumn{2}{|c|}{ Multivariate analysis } \\
\hline & P-value & $\mathrm{HR}$ & $95 \% \mathrm{CI}$ & P-value \\
\hline Id-1 (negative vs. positive) & 0.006 & 33.731 & $0.481-2,365.901$ & 0.105 \\
\hline $\mathrm{NF}-\kappa \mathrm{B}$ p65 (negative vs. positive) & 0.016 & 5.005 & $1.155-21.684$ & 0.031 \\
\hline Id-1 \& NF- $\kappa$ B p65 (negative/negative or positive/positive) & 0.002 & 6.953 & $1.605-30.123$ & 0.01 \\
\hline
\end{tabular}

Id-1, inhibitor of differentiation 1; HR, hazard ratio; CI, confidence interval.

and malignancy, involving poor histological grades, lymph node metastasis, vascular invasion and invasive interstitial depth $(\mathrm{P}<0.05)$.

The 5-year cumulative survival rate for the 65 patients was $70 \%$. In total, 19 patients died due to tumor recurrence within 2 years $(29.2 \%)$. As shown in Fig. 1C, subjects in the 'd' group had a poorer prognosis compared with the controls (log rank $\mathrm{P}=0.018$ ). As expected, apart from the co-expression of Id-1 and nuclear $\mathrm{NF}-\kappa \mathrm{B}$ p65, either Id-1 or nuclear $\mathrm{NF}-\kappa \mathrm{B}$ p65 expression was also a statistically significant prognostic indicator (Table II). However, only the co-expression of Id-1 and

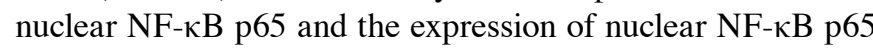
were independent prognostic factors, as shown by the multivariate analysis $(\mathrm{P}=0.031$ and $\mathrm{P}=0.01$, respectively; Table II $)$.
Co-expression of Id-1 and nuclear $N F-\kappa B$ p65 in cervical cancer cell lines. To determine the protein expression levels of Id-1, nuclear NF- $\mathrm{B}$ p 65 and $\mathrm{I} \kappa \mathrm{B}-\alpha$ in vitro, western blot analysis was performed. As shown in Fig. 2A, Id-1 and nuclear NF- $\kappa$ B p65 were expressed at significantly higher levels in SiHa or HeLa cells than in $\mathrm{H} 8$, whereas the lower expression of $\mathrm{I} \kappa \mathrm{B}-\alpha$ was detected in the cancer cell lines. RT-qPCR was then performed to detect the relative mRNA level of Id-1 (Fig. 2B). Significant differences were found when comparing the $\mathrm{SiHa}(36.15 \pm 2.63)$ and $\mathrm{HeLa}$ (13.29 \pm 0.83$)$ with $\mathrm{H} 8(1.01 \pm 0.15 ; \mathrm{P}<0.001)$. These results in vitro were in agreement with the findings in human tissues.

Id-1 expression is closely associated with the activity of the NF- $\kappa B$ signaling pathway. Initially, the four stable 
A

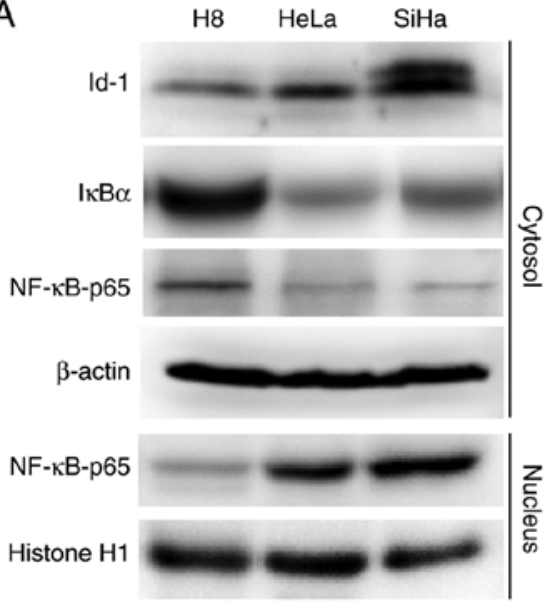

C

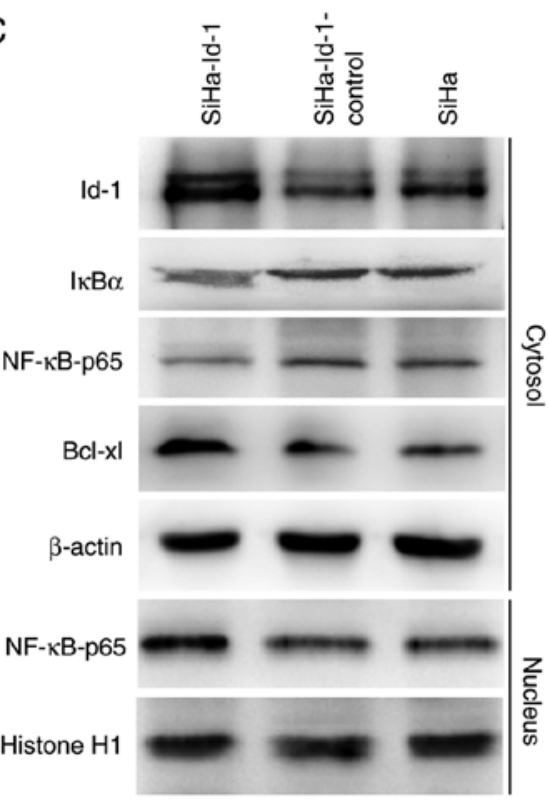

E

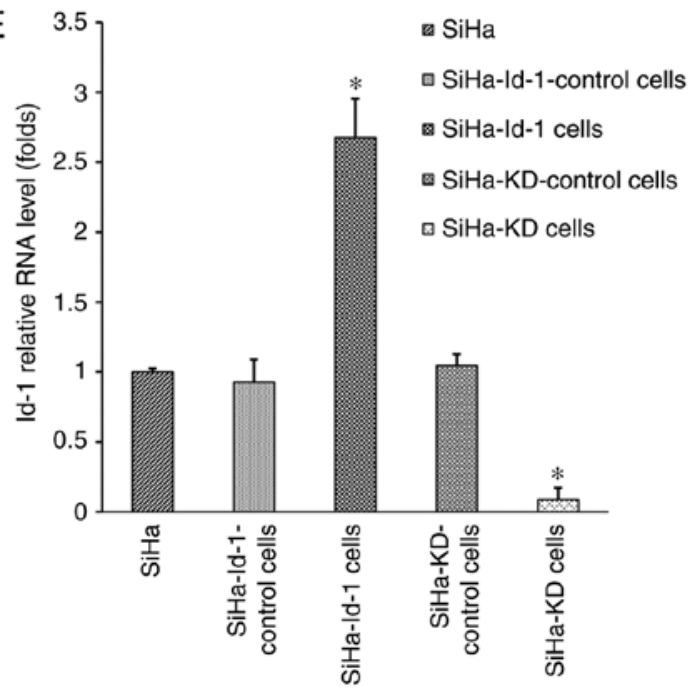

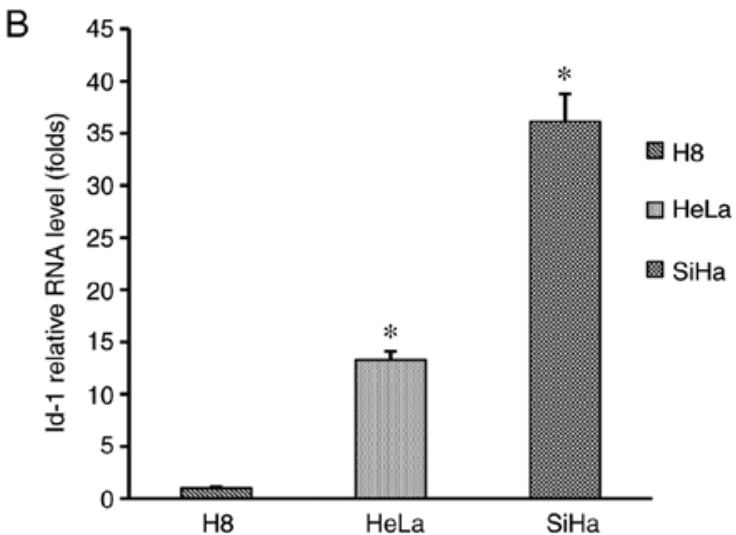
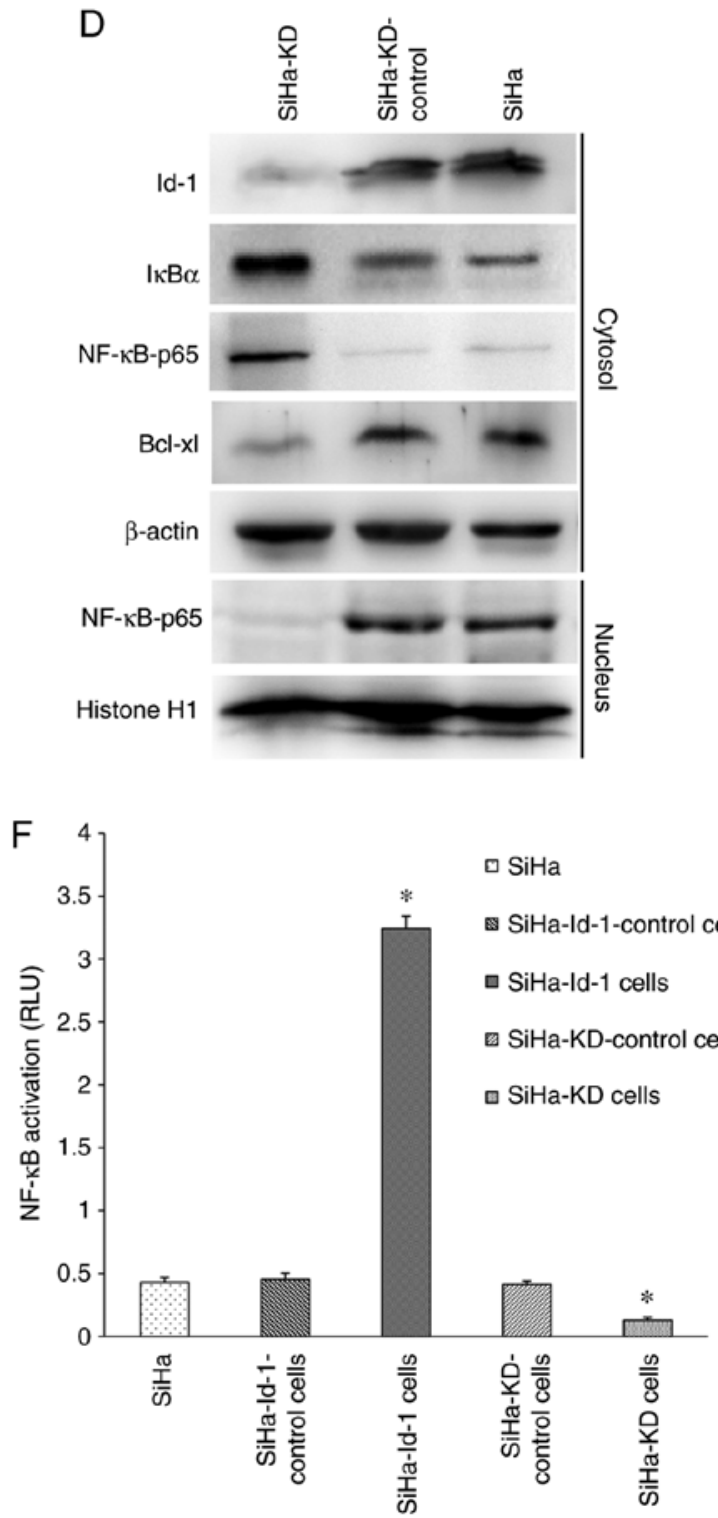

Figure 2. Synchronous co-expression of Id-1 and nuclear NF- $\mathrm{kB}$ p65 in cervical cell lines and the effects of Id-1 expression on NF- $\mathrm{B}$ signaling pathway.

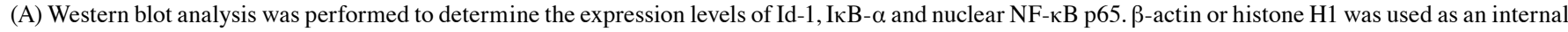
control for whole or nuclear protein, respectively. Representative images are shown. (B) Id-1 mRNA was detected by reverse transcription-quantitative PCR. B2M was used as an internal control. The data are expressed as folds of increase compared to H8 ("P<0.001 vs. H8). Western blot analysis was performed to

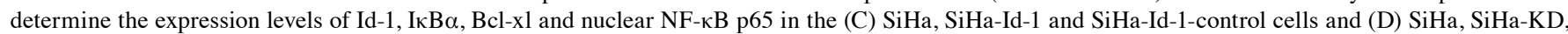
SiHa-KD-control. $\beta$-actin or histone H1 was used as an internal control. Representative images are shown. (E) Id-1 mRNA was detected by quantitative RT-PCR in the corresponding cells. B2M was used as an internal control. The data are expressed as folds of increase compared to the controls ("P $<0.001$ vs. respective control). (F) NF- $\mathrm{kB}$ transcription activity was detected by a dual-luciferase reporter gene assay in the corresponding cells. The data are presented as relative luciferase units ( $\mathrm{P}<0.001 \mathrm{vs}$. respective control). Id-1, Id-1, inhibitor of differentiation 1; I $\mathrm{k} \mathrm{B} \alpha$, inhibitor of $\kappa \mathrm{B}$. 

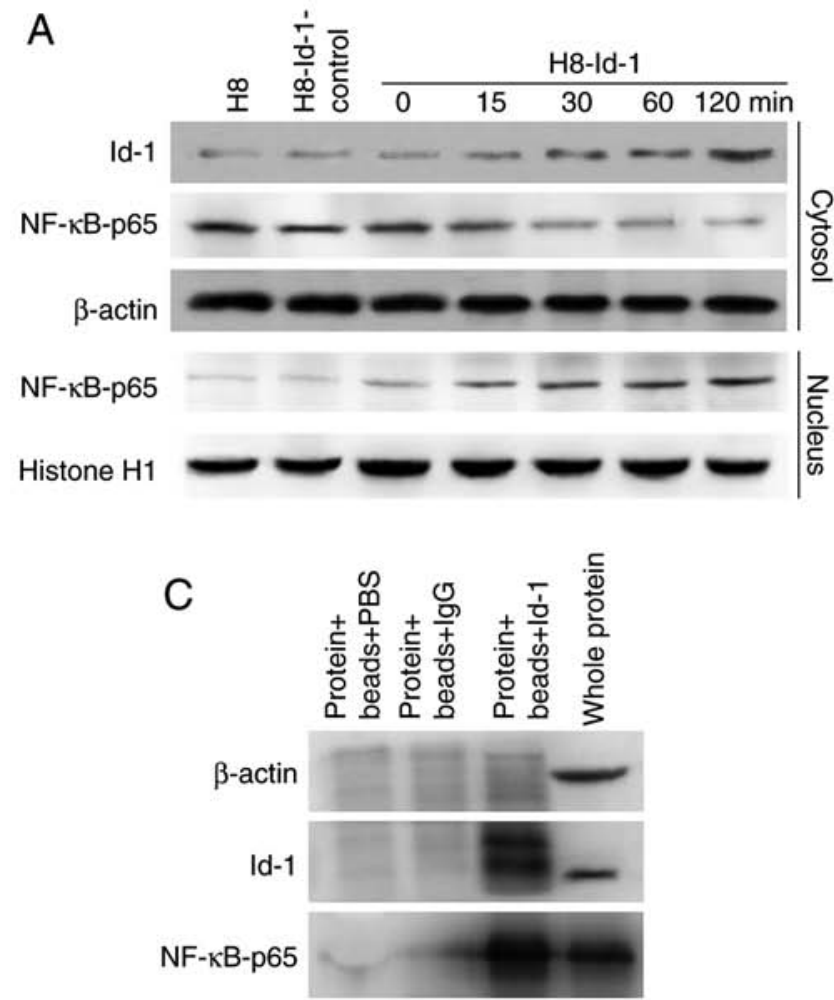
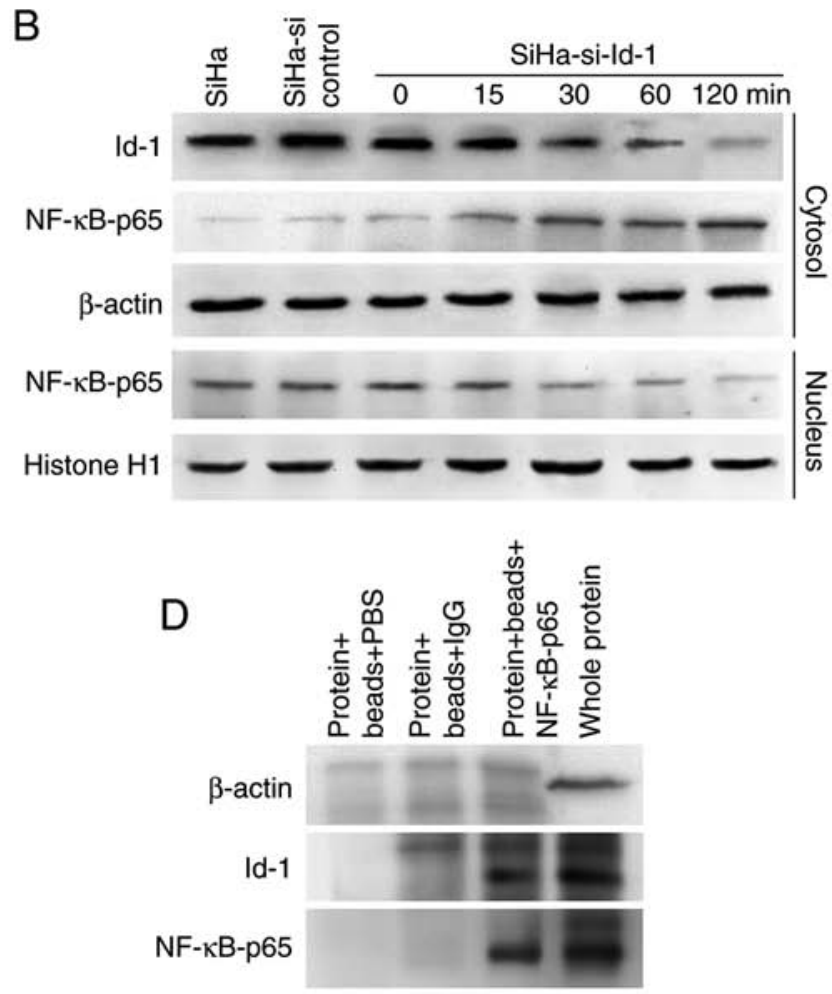

Figure 3. Time-dependent activation of NF- $\kappa$ B by Id-1 and co-immunoprecipitation. Western blot analysis was performed in (A) H8-Id-1 cells and (B) SiHa-si-Id-1 cells. Transient transfection of Id-1 overexpression plasmids or silencing plasmids resulted in a time-dependent synchronized alteration in the nuclear expression of NF- $\mathrm{B}$ p65. $\beta$-actin or Histone $\mathrm{H} 1$ was used as an internal control for whole or nuclear protein, respectively. Co-immunoprecipitate of (C) Id-1 and(D) NF-кB-p65 proteins from the SiHa cells. Id-1, Id-1, inhibitor of differentiation 1; si, small interfering RNA.

reconstructive cells were examined for the expression status of Id-1 transcripts by RT-qPCR and western blot analysis (Fig. 2C-E). Id-1 expression at the mRNA and protein level was markedly downregulated in the SiHa-KD cells compared with the controls $(\mathrm{P}<0.001$; Fig. $2 \mathrm{E})$, indicating that the Id-1 gene was effectively silenced. Conversely, the SiHa-Id-1 cells exhibited significantly elevated levels of Id-1 transcripts in comparison to the controls $(\mathrm{P}<0.001$; Fig. $2 \mathrm{E})$, demonstrating that the activity of the Id-1 gene was effectively intensified. However, there were no significant differences between the $\mathrm{SiHa}$, SiHa-KD-control and SiHa-Id-1-control cells (P>0.05; Fig. 2E).

Subsequently, the expression levels of nuclear NF- $\mathrm{BB}$ p65 and I $\kappa$ B- $\alpha$ were determined by western blot analysis (Fig. 2C and D). The up or downregulation of nuclear NF- $\kappa \mathrm{B}$ p65 was observed in the SiHa-Id-1 cells or SiHa-KD cells, respectively compared with the controls, whereas I $\mathrm{BB}-\alpha$ was expressed at a lower or higher level in the corresponding cells. Moreover, NF- $\mathrm{B}$ transcriptional activity was also markedly increased and decreased in the SiHa-Id-1 cells or SiHa-KD cells, respectively $(\mathrm{P}<0.001$; Fig. $2 \mathrm{~F})$. These results suggested that the expression status or activity of nuclear $\mathrm{NF}-\kappa \mathrm{B}$ p 65 was closely associated with Id-1, while I $\kappa$ B- $\alpha$ essentially displayed an opposite change in expression. Moreover, the expression of the immediate downstream effector of NF- $\kappa \mathrm{B}, \mathrm{Bcl}-\mathrm{xl}$, was also found to be increased or decreased with Id-1 up- or downregulation, respectively (Fig. 2C and D).

Time-dependent activation of $N F-\kappa B$ by Id-1, and co-immunoprecipitation. Id-1 expression exhibited a trend towards a

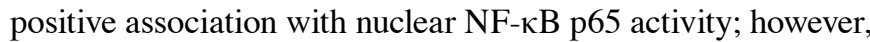
the mechanism involved is not clear. Since NF- $\kappa$ B translocates to the nucleus upon activation and is time-dependent, the expression of NF- $\kappa$ B p65 in the nuclear extracts and Id-1 in whole lysates was examined by western blot analysis of H8-Id-1 cells and SiHa-si-Id-1 cells. As shown in Fig. 3A and B, the transient transfection of $\mathrm{H} 8$ cells with Id-1 overexpression plasmids and SiHa cells with Id-1 siRNA plasmids indicated that the expression of Id-1 resulted in a time-dependent synchronized alteration in the nuclear expression of NF- $\kappa \mathrm{B}$ p65. Furthermore, it was sought to determine whether an Id-1-NF- $\kappa$ B p65 complex or interaction existed in the SiHa cells. As shown in Fig. 3C and $\mathrm{D}$, immunoprecipitation with Id-1 protein from the $\mathrm{SiHa}$ cells and hybridization to NF- $\kappa \mathrm{B}$ p65 antibody indicated the binding of NF- $\kappa \mathrm{B}$ p 65 protein. This interaction was further confirmed by the hybridization of Id-1 antibody to immunoprecipitates of NF- $\kappa \mathrm{B}$ p65 protein from SiHa cells.

Effects of Id-1 on tumor cell properties in vitro. WST assay was performed to detect tumor cell proliferative potential (Fig. 4A). The SiHa-KD cells grew at a significantly slower rate than the controls $(\mathrm{P}<0.001)$. Conversely, the overexpression of Id-1 transcripts in the SiHa-Id-1 cells significantly increased cell proliferative activity $(\mathrm{P}<0.01)$.

The cell migratory potential was measured by a wound healing assay (Fig. 4B and C). The migratory activity of the SiHa-KD cells was significantly decreased following Id-1 gene knockdown $(\mathrm{P}<0.001)$, whereas the SiHa-Id-1 cells exhibited a significantly increased migratory ability in comparison to the controls $(\mathrm{P}<0.001)$. 

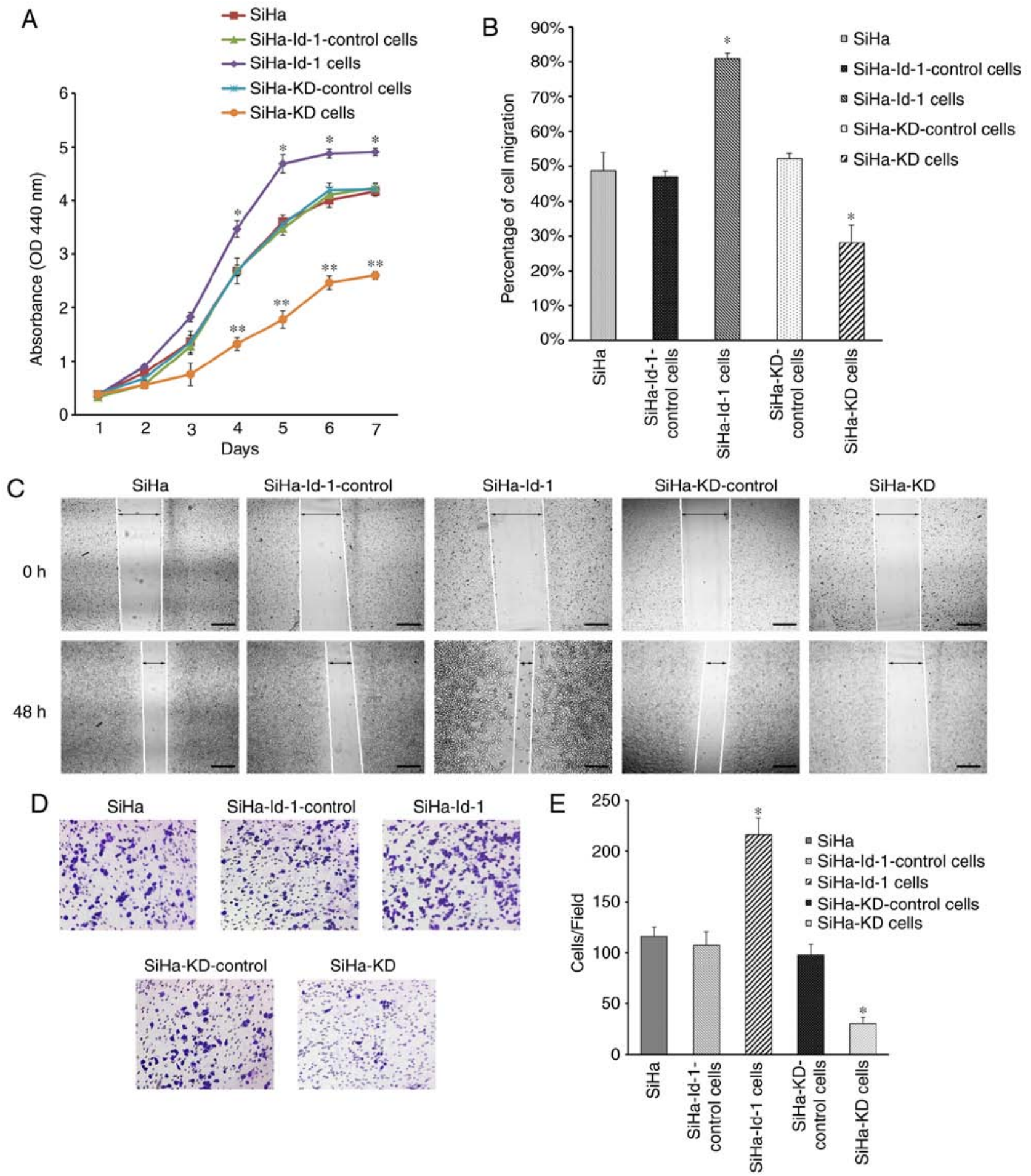

Figure 4. Analysis of cell malignant properties. (A) Proliferation was evaluated by WST assay ( $\left(\mathrm{P}<0.01,{ }^{* *} \mathrm{P}<0.001\right.$ vs. respective controls). Migration was measured by wound healing assay ("P<0.001) with (B) statistical analysis and $(C)$ representative images ( $\mathrm{x} 100)$. Scale bar, $100 \mu \mathrm{m}$. Cell invasion was examined by Matrigel invasion assay ( $\left.{ }^{*} \mathrm{P}<0.001\right)$ with (D) representative images ( $\left.\mathrm{x} 400\right)$ and $(\mathrm{E})$ statistical analysis. Id-1, Id-1, inhibitor of differentiation 1; KD, knock down .

Tumor cell invasive potential was evaluated by Matrigel invasion assay. As shown in Fig. 4D and E, a lower Id-1 expression in SiHa-KD cells was found to effectively inhibit invasion $(\mathrm{P}<0.001)$, while the invasive potential of the SiHa-Id-1 cells was increased significantly following Id-1 gene overexpression $(\mathrm{P}<0.001)$.

Id-1 is associated with cell chemosensitivity to cisplatin by regulating the expression of survival genes related to $N F-\kappa B$.
At first, a WST assay was performed to detect the cytotoxic effects of cisplatin and cell viability. As shown in Fig. 5A, the viability of the $\mathrm{SiHa}-\mathrm{KD}$ cells treated with cisplatin was significantly decreased compared with the SiHa-KD control $(5 \mu \mathrm{g} / \mathrm{ml}$, $\mathrm{P}<0.01 ; 10 \mu \mathrm{g} / \mathrm{ml}, \mathrm{P}<0.001)$. By contrast, the upregulation of Id-1 in the SiHa-Id-1 cells led to an enhanced chemoresistance compared to SiHa-Id-1 control $(10 \mu \mathrm{g} / \mathrm{ml}, \mathrm{P}<0.001)$.

The detection of apoptotic cells using JC-1 was then performed. As shown in Fig. 5B and C, the apoptotic cells, 
A

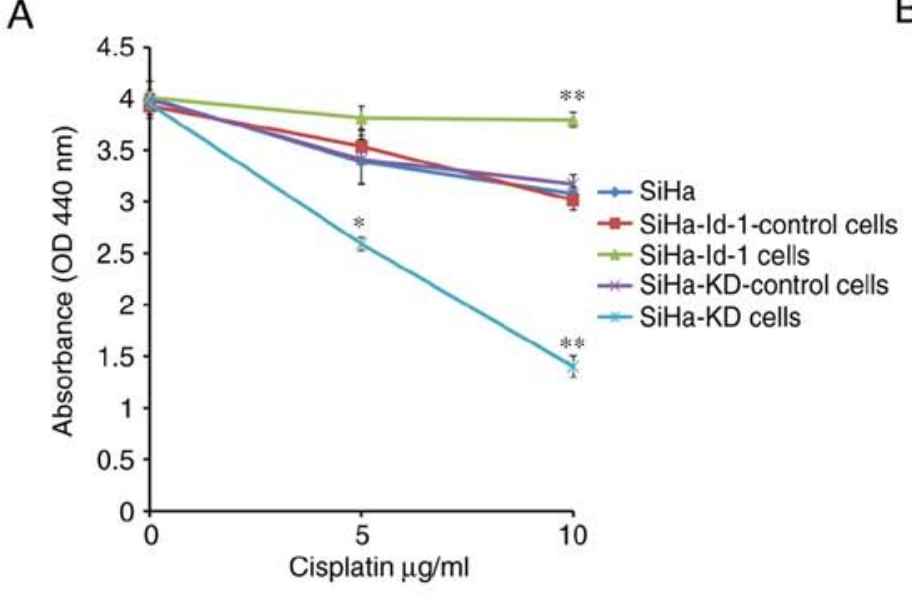

$\mathrm{B}$

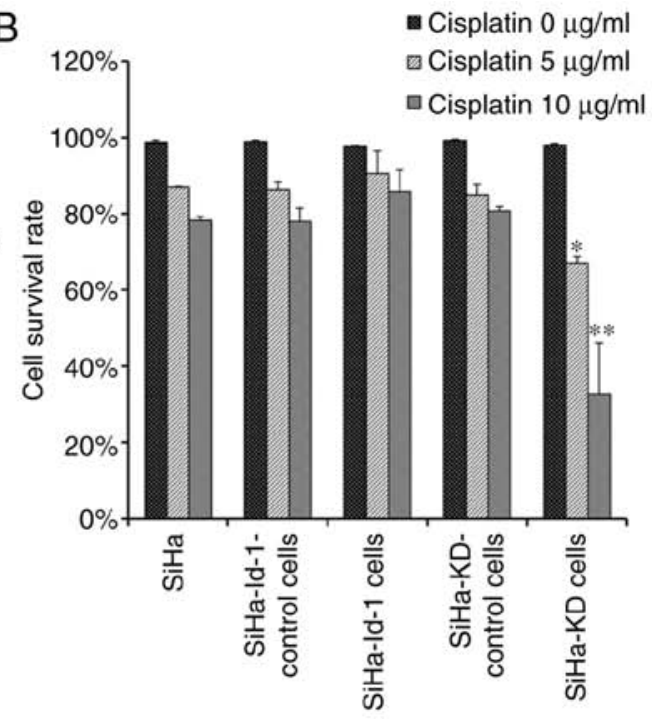

C
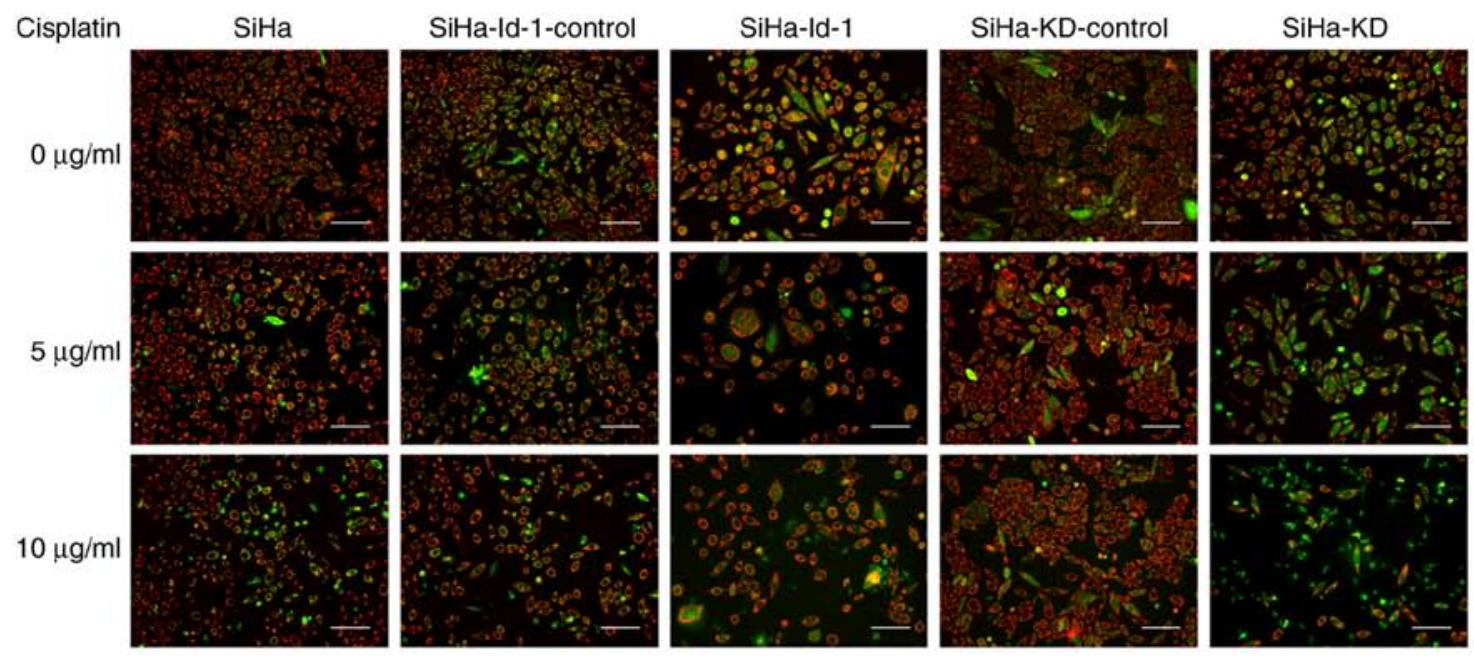

D
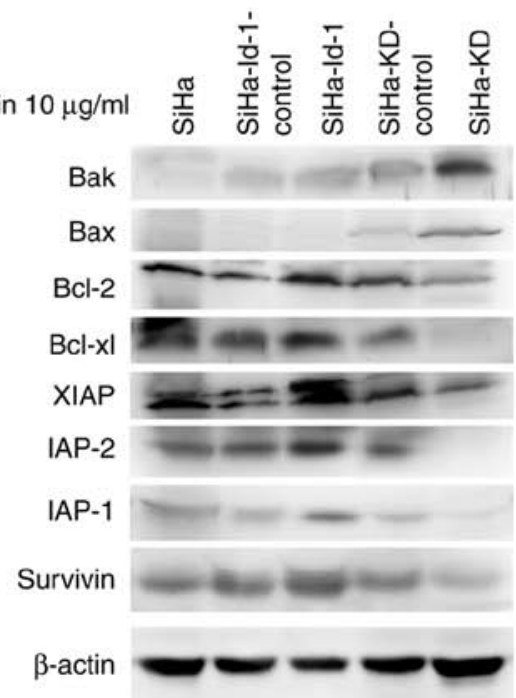

Figure 5. Id-1 protects SiHa cells from cisplatin-induced apoptosis via activation of survival genes related to NF- $\mathrm{kB}$. (A) WST assay was done to detect the cytotoxic effect of cisplatin and cell viability $\left({ }^{*} \mathrm{P}<0.01,{ }^{* *} \mathrm{P}<0.001\right)$. (B) Apoptosis analysis using JC-1 $\left({ }^{*} \mathrm{P}<0.01,{ }^{* *} \mathrm{P}=0.001 \mathrm{vs} .0 \mu \mathrm{g} / \mathrm{ml}\right.$ cisplatin). (C) Representative images od apoptotic cells stained with JC-1, primarily green fluorescence and shrinkage in morphology, but viable cells showed both red and green fluorescence (x200). Scale Bar: $100 \mu \mathrm{m}$. (D) Apoptotic markers related to NF- $\kappa B$ were detected using western blot analysis. $\beta$-actin was used as an internal control. OD, optical density; Id-1, inhibitor of differentiation 1; KD, knock down; XIAP, X-linked inhibitor of apoptosis; IAP, inhibitor of apoptosis.

exhibiting primarily green fluorescence and a shrinkage in morphology, were easily differentiated from the viable cells emitting red and green fluorescence. The effect of cisplatin-induced apoptosis was concentration-dependent. Notably, 
the percentage of surviving cells was significantly reduced in the SiHa-KD cells compared with the SiHa-KD control cells $(5 \mu \mathrm{g} / \mathrm{ml} \mathrm{P}<0.01,10 \mu \mathrm{g} / \mathrm{ml} \mathrm{P}=0.001)$. However, only a few apoptotic cells were observed in the SiHa-Id-1 cells following exposure to cisplatin $(\mathrm{P}>0.05)$.

The immediate downstream effectors of $N F-\kappa B$, including Bcl-2, Bcl-xl, Survivin, XIAP, IAP-1, IAP-2, Bax and Bak, were then detected by western blot analysis (Fig. 5D). Following exposure to $10 \mu \mathrm{g} / \mathrm{ml}$ cisplatin, expression of anti-apoptotic proteins, including Bcl-2, Bcl-xl, Survivin, XIAP, IAP-1 and IAP-2, was significantly decreased in the SiHa-KD cells, while the expression levels of the pro-apoptotic proteins, Bax and Bak, were higher than the controls. However, the proteins associated with apoptosis exhibited the opposite change in expression in the SiHa-Id-1 cells compared with the controls.

\section{Discussion}

The present study demonstrated that the elevated co-expression of Id-1 and nuclear NF- $\mathrm{KB}$ p65 was more frequently associated with cervical cancer progression, aggressive behaviors and poorer clinical outcomes, further suggesting an increased resistance to chemotherapy. Simultaneously, targeting Id-1 with shRNA or Id-1 overexpression lentivirus in SiHa cells had a trend towards a synchronous association with nuclear $\mathrm{NF}-\kappa \mathrm{B}$ p65 activity and cell survival capacity. More importantly, the current study demonstrated physical interaction of Id-1 and NF- $\kappa$ B p65 in SiHa cells. This study also indicated that the survival-promoting effect of Id-1 may be attributed to the subsequent activation of the $N F-\kappa B$ signaling pathway, suggesting the possible mechanisms for tumor cell survival and chemoresistance.

Although Id-1 is known to have a critical role in tumorigenesis, metastasis and progression in a variety of cancers (16-18), the exact role of Id-1 in cervical cancer remains unclear. In this study, it was demonstrated that Id-1 expression was significantly elevated in cervical cancer tissues and in cultured cancer cell lines. Recently, a few studies have suggested the potential association between Id-1 and NF- $\kappa \mathrm{B}$ in human cancers, indicating that $\mathrm{NF}-\kappa \mathrm{B}$, an important downstream signaling pathway of Id-1, may be responsible for some effects of Id-1 (19-21). However, the association of Id-1 with NF- $\kappa \mathrm{B}$ has not yet been addressed yet in cervical cancer to date, to the best of our knowledge. This study provided the evidence of the synchronous elevated co-expression of Id-1 and nuclear NF- $\mathrm{B}$ p 65 both in vivo and in vitro; moreover, the data suggested a strong linear correlation between them. The association of these oncoproteins with the patient characteristics and prognosis were also evaluated. The findings demonstrated that cervical cancers with the co-expression of Id-1 and nuclear NF- $\mathrm{NB}$ p65 were more frequently linked to a variety of clinical parameters associated with cancer aggressiveness and metastasis. Perhaps the most novel points arising from the current study is that compared with the separate expression of Id-1 or nuclear NF- $\mathrm{B}$ p 65, co-expression of the both conferred significantly poorer prognosis and was an independent, strong indicator of survival in cervical cancer. However, previous studies have only indicated that either of the two oncoproteins was closely associated with cervical cancer malignancy and a poor prognosis $(9,13)$.

Nevertheless, it remains to be determined whether the coordinated regulation of $\mathrm{Id}-1$ and nuclear $\mathrm{NF}-\kappa \mathrm{B}$ p65 contributes to cervical cancer progression and metastasis. In this study, shRNA and the Id-1 overexpression lentivirus were used to modulate expression of Id-1 transcripts in $\mathrm{SiHa}$ cells. Since the nuclear translocation and activation of $\mathrm{NF}-\kappa \mathrm{B}$ is essentially dependent on I $\mathrm{B}-\alpha$ degradation in the cytoplasm (22), IкB- $\alpha$ was detected in the corresponding cells. I $\kappa-\alpha$ essentially displayed an opposite change in expression to Id-1 and NF- $\mathrm{BB}$ p65. After promoting Id-1 gene expression in the SiHa cells, expression of I $\kappa \mathrm{B}-\alpha$ was significantly decreased and nuclear translocation of $N F-\kappa B$ p 65 was significantly increased, indicating that Id-1 is a positive regulator of the NF- $\kappa \mathrm{B}$ signaling pathway. These findings are in agreement with earlier observations in lung cancer, colon cancer and esophageal cancer (23-25). Moreover, the data indicated that silencing the Id-1 gene markedly inhibited cell proliferation, migration and invasion, whereas the ectopic expression of Id-1 resulted in the stimulation of cell malignant properties. These observations are consistent with previous findings (26). Given these observations, it is apparent that Id-1 is crucial gene in tumors. The mechanisms may involve several molecules associated with $\mathrm{NF}-\kappa \mathrm{B}$, which controls aggressive cellular phenotypes (27-29).

However, the mechanisms responsible for Id-1 activation of NF- $\kappa \mathrm{B}$ have not yet been fully elucidated. Since this study provides the first evidence, to the best of our knowledge, that an Id-1-NF- $\kappa$ B p65 complex may exist in the SiHa cells, the two oncoproteins may cooperate to promote cervical carcinogenesis. However, the details underlying their physical combination are far from being understood. Li et al (30) indicates that the PI3K/Akt signaling pathway serves as a link between Id-1 and NF- $\mathrm{BB}$ in esophageal cancer cells. However, Yang et al (31) demonstrated that Id-1 potentiates $\mathrm{NF}-\kappa \mathrm{B}$ activation upon $\mathrm{T}$ cell receptor signaling in $\mathrm{T}$ cells. It is speculated that there may be more potential mechanisms responsible for Id-1 and $\mathrm{NF}-\kappa \mathrm{B}$ interaction, which warrants further investigations.

The present study further suggested that Id-1 expression was associated with cell chemosensitivity to cisplatin, and the activation of survival genes via $\mathrm{NF}-\kappa \mathrm{B}$. The results revealed that reduced activity of the $\mathrm{NF}-\kappa \mathrm{B}$ signaling pathway mediated by the silencing of the Id-1 gene in SiHa cells led to significantly increased anti-tumor responses to cisplatin compared with the controls, suggesting that Id-1 was able to protect tumor cells from apoptosis through the activation of the NF- $\mathrm{NB}$ signaling pathway. The result is supported by the studies of Li et al (23) and Lin et al (29) in other types of cancer. As the Id-1/NF- $\kappa$ B signaling pathway is widely involved in cervical cancer progression, invasion and chemoresistance, this may suggest a prospective therapeutic strategy for cervical cancer. Some new agents targeting NF- $\kappa \mathrm{B}$ have been developed (32), while Id-1, as the upstream regulator of $\mathrm{NF}-\kappa \mathrm{B}$, should also be considered as an alternative target for cancer therapy.

In conclusion, the synchronous co-expression of Id-1 and nuclear $\mathrm{NF}-\kappa \mathrm{B}$ p 65 has a prominent role in many aspects of cervical cancer, suggesting that the combined analysis of Id-1 and $\mathrm{NF}-\kappa \mathrm{B}$ may help to predict malignant properties and a poor 
prognosis. Apart from NF- $\kappa \mathrm{B}$, Id-1 should also be developed as a promising therapeutic strategy for cervical cancer. Reagents targeting Id-1/NF- $\kappa$ B may have important clinical implications.

\section{Acknowledgements}

Not applicable.

\section{Funding}

This study was supported by Sichuan Science and Technology Program of China (grant nos. 2018SZ0248 and 2019YFS0404)

\section{Availability of data and materials}

All data generated or analyzed during this study are included in this published article.

\section{Authors' contributions}

$\mathrm{ZW}, \mathrm{YZ}$, and XP performed the experiments, acquired the data and drafted the manuscript. JL, LH and XP collected the tissue samples. YZ and JL analyzed and interpreted the data. All authors have read and approved the final manuscript and agreed to be accountable for all aspects of the research in ensuring that the accuracy or integrity of any part of the work are appropriately investigated and resolved.

\section{Ethics approval and consent to participate}

All procedures performed in experiments involving human participants were in accordance with the ethical standards of the institutional and/or national research committee and with the 1964 Helsinki declaration and its later amendments or comparable ethical standards. The present study was approved by the Institutional Ethical Board of the West China Second University Hospital, Sichuan University. Informed consent was obtained from all individual participants included in the study.

\section{Patient consent for publication}

Not applicable.

\section{Competing interests}

The authors declare that they have no competing interests.

\section{References}

1. Bray F, Ferlay J, Soerjomataram I, Siegel RL, Torre LA and Jemal A: Global cancer statistics 2018: GLOBOCAN estimates of incidence and mortality worldwide for 36 cancers in 185 countries. CA Cancer J Clin 68: 394-424, 2018.

2. Fernandes JV, DE Medeiros Fernandes TA, DE Azevedo JC, Cobucci RN, DE Carvalho MG, Andrade VS and DE Araújo JM: Link between chronic inflammation and human papillomavirus-induced carcinogenesis (Review). Oncol Lett 9: 1015-1026, 2015

3. Perk J, Iavarone A and Benezra R: Id family of helix-loop-helix proteins in cancer. Nat Rev Cancer 5: 603-614, 2005.

4. Wong YC, Wang X and Ling MT: Id-1 expression and cell survival. Apoptosis 9: 279-289, 2004.
5. Han S, Gou C, Hong L, Liu J, ZheyiHan, Liu C, Wang J, Wu K, Ding J and Fan D: Expression and significances of Id1 helix-loop-helix protein overexpression in gastric cancer. Cancer Lett 216: 63-71, 2004.

6. Cho Y, Cho EJ, Lee JH, Yu SJ, Kim YJ, Kim CY and Yoon JH: Fucoidan-induced ID-1 suppression inhibits the in vitro and in vivo invasion of hepatocellular carcinoma cells. Biomed Pharmacother 83: 607-616, 2016.

7. Jang KS, Han HX, Paik SS, Brown PH and Kong G: Id-1 overexpression in invasive ductal carcinoma cells is significantly associated with intratumoral microvessel density in ER-negative/node-positive breast cancer. Cancer Lett 244: 203-210, 2006.

8. Zielinski AJ, Fong S, Allison J, Kawahara M, Coppe JP, Feiler H, Lee NM and Desprez PY: The helix-loop-helix Id-1 inhibits PSA expression in prostate cancer cells. Int J Cancer 126: 2490-2496, 2010.

9. Li J, Jia H, Xie L, Wang X, He H, Lin Y and Hu L: Correlation of inhibitor of differentiation 1 expression to tumor progression, poor differentiation and aggressive behaviors in cervical carcinoma. Gynecol Oncol 114: 89-93, 2009.

10. Pikarsky E, Porat RM, Stein I, Abramovitch R, Amit S, Kasem S, Gutkovich-Pyest E, Urieli-Shoval S, Galun E and Ben-Neriah Y: NF-kappaB functions as a tumour promoter in inflammation-associated cancer. Nature 431: 461-466, 2004.

11. Karin M: Nuclear factor-kappaB in cancer development and progression. Nature 441: 431-436, 2006.

12. Chandrika G, Natesh K, Ranade D, Chugh A and Shastry P: Suppression of the invasive potential of Glioblastoma cells by mTOR inhibitors involves modulation of NFKB and PKC- $\alpha$ signaling. Sci Rep 6: 22455, 2016.

13. Li J, Jia H, Xie L, Wang X, Wang X, He H, Lin Y and Hu L: Association of constitutive nuclear factor-kappaB activation with aggressive aspects and poor prognosis in cervical cancer. Int J Gynecol Cancer 19: 1421-1426, 2009.

14. Peng X, Wu Z, Yu L, Li J, Xu W, Chan HC, Zhang Y and Hu L: Overexpression of cystic fibrosis transmembrane conductance regulator (CFTR) is associated with human cervical cancer malignancy, progression and prognosis. Gynecol Oncol 125: 470-476, 2012 .

15. Livak KJ and Schmittgen TD: Analysis of relative gene expression data using real-time quantitative PCR and the 2(-Delta Delta C(T)) method. Methods 25: 402-408, 2001.

16. Hao L, Liao Q, Tang Q, Deng H and Chen L: Id-1 promotes osteosarcoma cell growth and inhibits cell apoptosis via PI3K/AKT signaling pathway. Biochem Biophys Res Commun 470: 643-649, 2016.

17. Shuno Y, Tsuno NH, Okaji Y, Tsuchiya T, Sakurai D, Nishikawa T, Yoshikawa N, Sasaki K, Hongo K, Tsurita G, et al: Id1/Id3 knockdown inhibits metastatic potential of pancreatic cancer. J Surg Res 161: 76-82, 2010.

18. Forootan SS, Wong YC, Dodson A, Wang X, Lin K, Smith PH, Foster CS and Ke Y: Increased Id-1 expression is significantly associated with poor survival of patients with prostate cancer. Hum Pathol 38: 1321-1329, 2007.

19. Sun W, Guo MM, Han P, Lin JZ, Liang FY, Tan GM, Li HB, Zeng $M$ and Huang XM: Id-1 and the p65 subunit of NF-KB promote migration of nasopharyngeal carcinoma cells and are correlated with poor prognosis. Carcinogenesis 33: 810-817, 2012.

20. Su Y, Gao L, Teng L, Wang Y, Cui J, Peng S and Fu S: Id1 enhances human ovarian cancer endothelial progenitor cell angiogenesis via PI3K/Akt and NF-KB/MMP-2 signaling pathways. J Transl Med 11: 132, 2013.

21. Tsai CH, Yang MH, Hung AC, Wu SC, Chiu WC, Hou MF, Tyan YC, Wang YM and Yuan SF: Identification of Id1 as a downstream effector for arsenic-promoted angiogenesis via PI3K/Akt, NF-KB and NOS signaling. Toxicol Res (Camb) 5: 151-159, 2015.

22. Shin CH and Choi DS: Essential roles for the Non-canonical IKB kinases in linking inflammation to cancer, obesity, and diabetes. Cells 8: pii: E178, 2019.

23. Li J, Li Y, Wang B, Ma Y and Chen P: Id-1 promotes migration and invasion of non-small cell lung cancer cells through activating NF-KB signaling pathway. J Biomed Sci 24: 95, 2017.

24. Li B, Cheung PY, Wang X, Tsao SW, Ling MT, Wong YC and Cheung AL: Id-1 activation of PI3K/Akt/NFkappaB signaling pathway and its significance in promoting survival of esophageal cancer cells. Carcinogenesis 28: 2313-2320, 2007.

25. Porquet N, Poirier A, Houle F, Pin AL, Gout S, Tremblay PL, Paquet ER, Klinck R, Auger FA and Huot J: Survival advantages conferred to colon cancer cells by E-selectin-induced activation of the PI3K-NFKB survival axis downstream of Death receptor-3. BMC Cancer 11: 285, 2011. 
26. Ma H, Wei Y, Leng Y, Li S, Gao L, Hu H, Chen L, Wang F, Xiao H, Zhu C and Liang C: TGF- $\beta 1$-induced expression of Id- 1 is associated with tumor progression in gastric cancer. Med Oncol 31: 19, 2014

27. Roschger $\mathrm{C}$ and Cabrele $\mathrm{C}$ : The Id-protein family in developmenta and cancer-associated pathways. Cell Commun Signal 15: 7, 2017.

28. Ma J, Shi M, Li G, Wang N, Wei J, Wang T, Ma J and Wang Y Regulation of Id1 expression by epigallocatechin-3-gallate and its effect on the proliferation and apoptosis of poorly differentiated AGS gastric cancer cells. Int J Oncol 43: 1052-1058, 2013.

29. Lin J, Guan Z, Wang C, Feng L, Zheng Y, Caicedo E, Bearth E, Peng JR, Gaffney P and Ondrey FG: Inhibitor of differentiation 1 contributes to head and neck squamous cell carcinoma survival via the NF-kappaB/survivin and phosphoinositide 3-kinase/Akt signaling pathways. Clin Cancer Res 16: 77-87, 2010.
30. Li B, Tsao SW, Li YY, Wang X, Ling MT, Wong YC, He QY and Cheung AL: Id-1 promotes tumorigenicity and metastasis of human esophageal cancer cells through activation of PI3K/AKT signaling pathway. Int J Cancer 125: 2576-2585, 2009.

31. Yang Y, Liou HC and Sun XH: Id1 potentiates NF-kappaB activation upon $\mathrm{T}$ cell receptor signaling. J Biol Chem 281: 34989-34996, 2006.

32. Thulasidasan AKT, Retnakumari AP, Shankar M, Vijayakurup V, Anwar S, Thankachan S, Pillai KS, Pillai JJ, Nandan CD, Alex VV, et al: Folic acid conjugation improves the bioavailability and chemosensitizing efficacy of curcumin-encapsulated PLGA-PEG nanoparticles towards paclitaxel chemotherapy. Oncotarget 8: 107374-107389, 2017. 